\title{
Planning for Wellness Tourism Center in Isfahan Province, Iran
}

\author{
Zahra Nadim, Amir Gandomkar* \\ Department of Geography, Faculty of Humanities, Najafabad Branch, Islamic Azad University, Najafabad, Iran \\ Email: zahra_nadim@yahoo.com, ^agandomkar2007@yahoo.com
}

How to cite this paper: Nadim, Z. and Gandomkar, A. (2016) Planning for Wellness Tourism Center in Isfahan Province, Iran. Open Journal of Ecology, 6, 645-657. http://dx.doi.org/10.4236/oje.2016.610060

Received: May 10, 2016

Accepted: September 27, 2016

Published: September 30, 2016

Copyright $\odot 2016$ by authors and Scientific Research Publishing Inc. This work is licensed under the Creative Commons Attribution International License (CC BY 4.0).

http://creativecommons.org/licenses/by/4.0/ (c) (i) Open Access

\begin{abstract}
In today's life, because of industrial cities with long time of work, environmental pollutions and the aging of the population demanding to have leisure, recreation and outdoor recreations for every group of population, the necessity of construction a place for health outdoor recreation is obvious. Such a place would provide both entertaining in a happy family atmosphere and enjoying from fresh air, healthy food and nature cures like hydrotherapy, fish spa, herbs, acupuncture etc. for all the people from a kid to elderly guy and healthy to sick. This project was aimed to introduce and make a plan for constructing this site, known as wellness tourism center in Isfahan province, Iran. For reaching this purpose with taking advantage of original and second hand text, library resources, filed observations, specialist opinion on questionnaire, SPSS software and analysis and evaluation of statistical models with 2 -square test, the best plan for this site has been suggested.
\end{abstract}

\section{Keywords}

Planning, Wellness Tourism, Isfahan Province

\section{Introduction}

The world has urbanized rapidly. According to last researches, over the next fifteen years, 20 to 30 cities of the world will be over 20 millions populated and cities or environments constructed by human will be living place of most of world's population. Till 1990, at least 600 millions of people in developing countries are living in undesirable conditions of slums. At a same time of limiting the power and options of government, city officials have powerful forces and the world is becoming political and administrative decentralization [1].

In today's condition, it is necessary for governments, organizations and public institutions to evaluate and check the urban qualities in order to recognize available quali- 
ties, capacities and weaknesses, also possibility to more informed and targeted planning for eliminating the deficiency and promoting the city qualities [2].

In this era, people all over the world are more attracted to rejuvenation and wellness, preventing of premature aging and healthy living. Healthy and happy life is the top news and people are more eager to spend for maintaining their wellness and sickness preventation. Mixing preventive and wellness facilities with entertainment and happy activities in order to convince healthy guys to use them is effective.

According to World Health Organization in 2011, at least 1 million and 18 thousands of people were suffered from mental and spiritual problems. Due to the high potential of tourism and health tourism in Isfahan and society's demand to recreational and leisure places, site selecting for health recreational city has performed.

Health tourism includes 3 subdivisions: Wellness Tourism, Curative Tourism and Medical Tourism.

\section{Wellness Tourism}

Traveling to healthy villages and regions with mineral water and spas for freedom from everyday's life tensions and refection without interrupt and medical supervision for the cases with no specific physical illnesses, is called wellness tourism [3].

Wellness tourism is a travel aimed to improve health and wellness through physical, psychological and mental activities [4]. Stanford Research Institute (SRI) has defined wellness tourism in this way: all travels in order to keep and increase personal wellness of every person. Spa tourism is the main components of wellness tourism (41\%), but other part of wellness tourism market (non spa tourism) include healthy hotels and cruises, bath/springs, fitness, Yuga, traveling to natural parks, natural restaurants/ organic and other health accommodations, have allocated 59\% of this market to themselves (Figure 1).

\section{Hypotheses}

1) Nature therapy could be an appropriate alternative for medical cures.

2) One of the most important planning factors of wellness center is availability for area's residents.

3) The most attractive part of nature therapy for citizens is hydrotherapy.

\section{Study Area}

Isfahan is the third most populous metropolitan area in middle of Iran after Tehran and Mashhad. Isfahan is the capital of Isfahan province in Iran. According to Isfahan Municipality statistics Isfahan city has the area around 550 square kilometers that includes $0.5 \%$ of Isfahan province. Isfahan is located between $32^{\circ} 39^{\prime} 08^{\prime \prime}$ north latitude and $51^{\circ} 40^{\prime} 28^{\prime \prime}$ east longitude (Figure 2).

\subsection{International Health Tourism in the World}

The health tourism market is affected by the generating countries that have a profound 


\section{Wellness Travelers...}

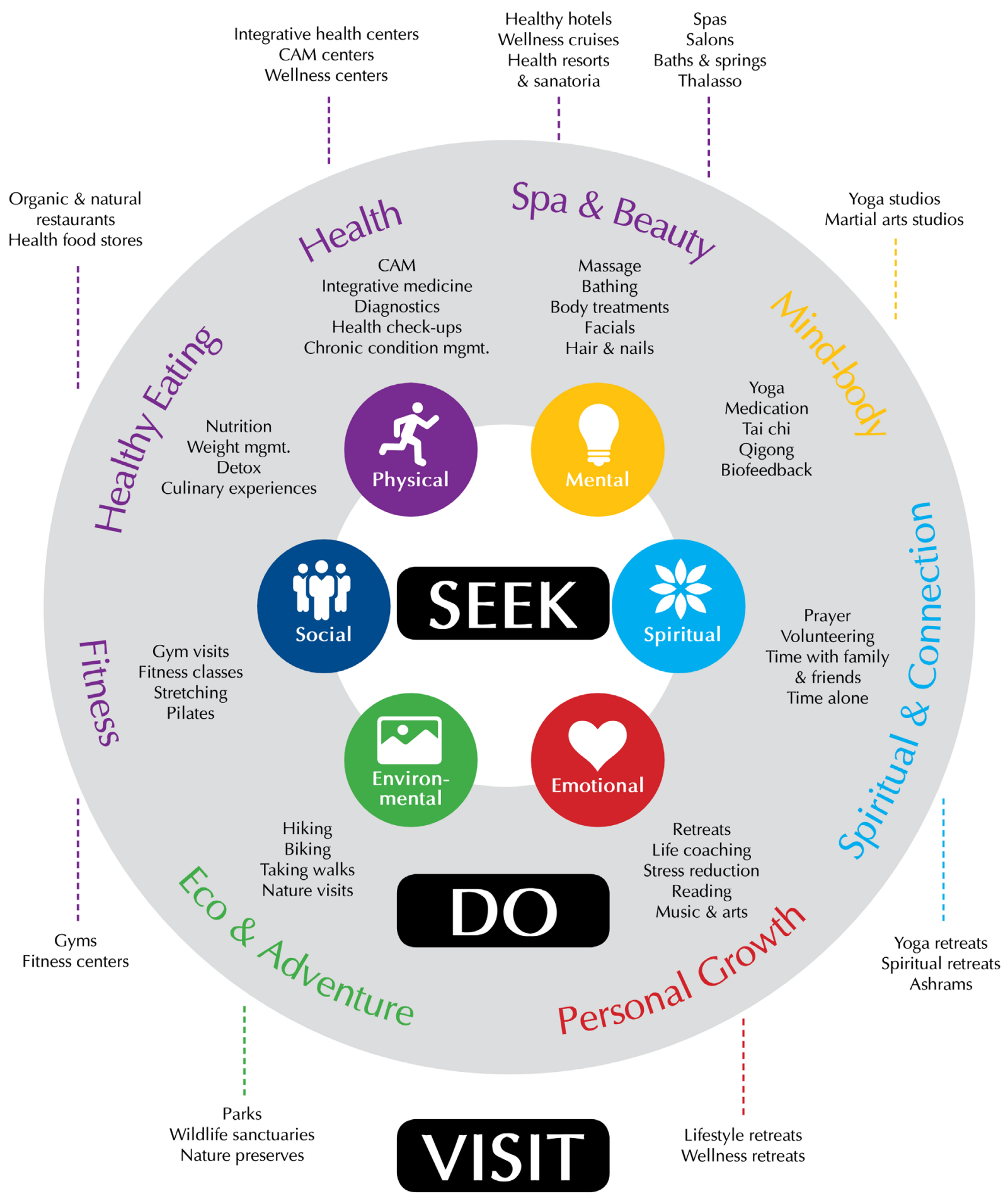

Figure 1. What wellness travelers seek? 


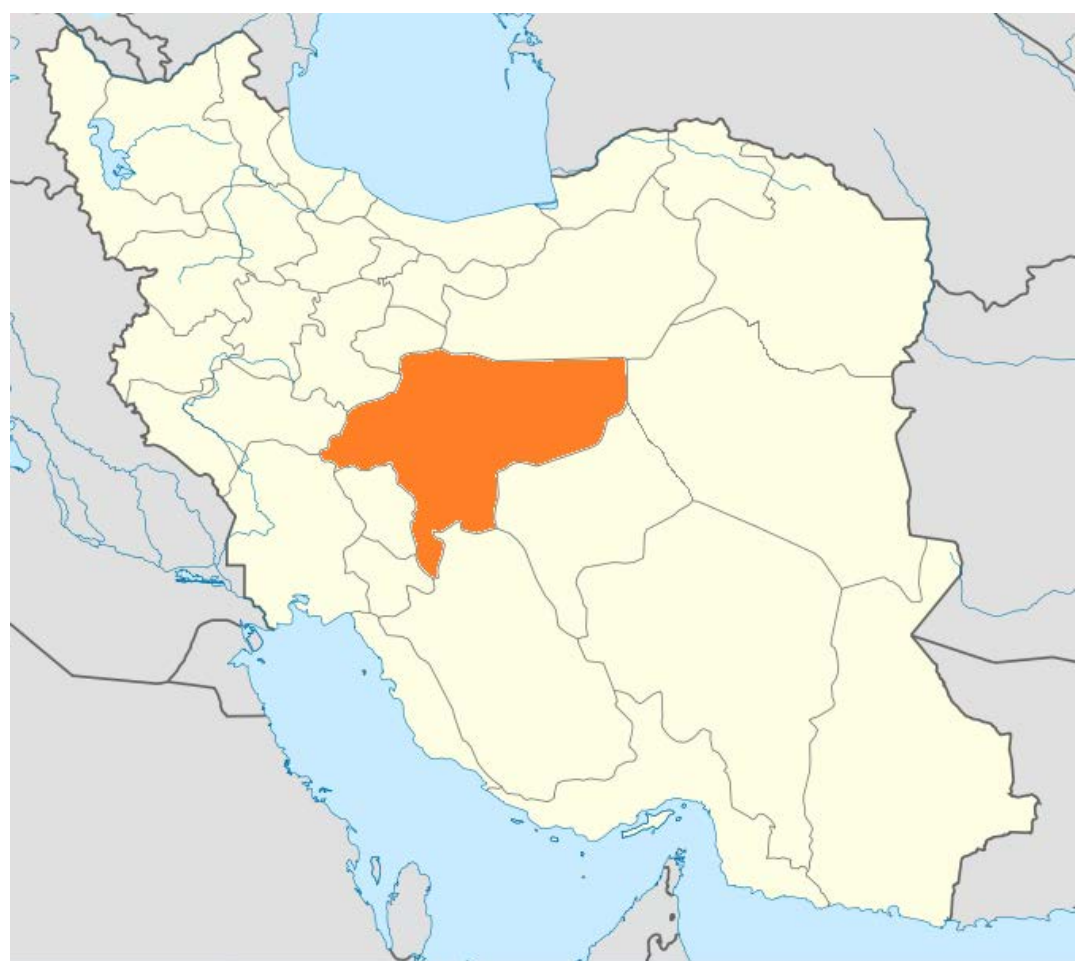

Figure 2. Study area (Isfahan city).

history and experience [5]. These include mainly, countries that have already established health tourism industries, such as Germany, USA, Japan, UK, France and Italy.

A new study presented at the inaugural Global Wellness Tourism Congress found wellness tourism is a near half-trillion dollar market, representing 14 percent of global tourism revenues overall. According to the Global Wellness Tourism Economy report, the category is projected to grow on average 9.9 percent annually over the next five years, nearly $\$ 678.5$ billion by 2017 , or 16 percent of total tourism revenues. the study also noted over one-half of growth in wellness tourism through 2017 will come from the Asian, Latin American and Middle Eastern/North African markets, and India will be number one globally over the next five years, clocking a 20 percent-plus growth through 2017. And wellness tourists are higher spenders, on average, spending 130 percent more than the average global tourist. Wellness tourism is directly responsible for $\$ 11.7$ million global jobs, which delivers $\$ 1.3$ trillion in global economic impact-or 1.8 percent of world's GDP in 2012 [6] (Figure 3).

\subsection{Health Tourism in Iran}

Iran based on World Bank classification is a country with average to high salary income and forth biggest country in Asia and seventeenth large country in the world with located in Middle East and possess 1,648,195 square kilometer area. World health organization had sorted Iran in eastern Mediterranean district. Health tourism is not a new phenomenon in Iran. In past neighbor countries including Arabian countries around Persian Gulf were traveling to Iran for reaching health care services [7]. 


\section{GLOBAL WELLNESS}

INSTITUTETM

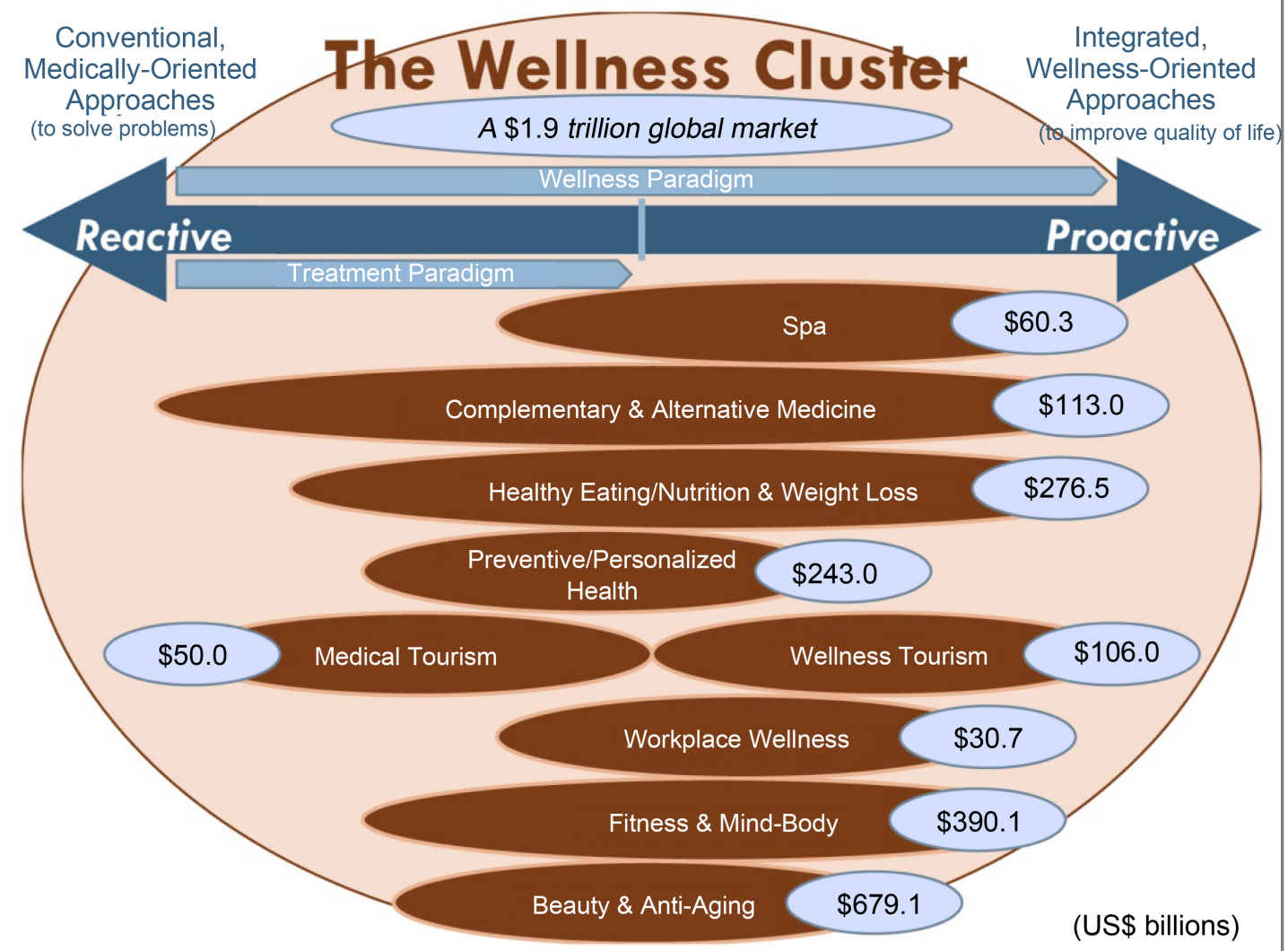

(C) Global Wellness Institute. Originally published in

"Spas \& the Global Wellness Market: Synergies \& Opportunities," 2010

Figure 3. The wellness cluster (Source: Stanford research institute).

Iran due to advantages in health tourism including low cost services with high quality, expert doctors and lots of natural attractions intended to enter to this industry [8].

Health care tourism would result in gaining foreign exchange, improvement the level of life, increasing the nation's capitation, increasing the mobility of production and distribution and making jobs and services directly and indirectly in the country. So that each tourist causes 8 jobs including 3 direct and 5 indirect jobs [9].

\subsection{Introducing Wellness Tourism Center}

Ophelia Yeung (SRI project manager at science, technology and economy development) believed that: for decades recreation's definition were accompanied with Indulgence: Excess in eating and lack of sleeping. So that travelers come back to their coun- 
tries with less healthiness than before arrival. Her research showed that nowadays people are choosing destinations that help them to keep and improve their healthiness (Stanford Research Institute).

Wellness tourism center is a city in which with natural facilities and without demanding to chemical medicines and operations for healthy people in all age categories and sicknesses health services are available. Natural facilities are include: hydrotherapy, spas, thalassotherapy, mud therapy, traditional medicine, acupuncture, solarium treatment, energy therapy, yoga, meditation, homeopathy, stone therapy, jewelry therapy, aromatherapy, herbal therapy, sand therapy, animal therapy, leech therapy, bee therapy, massage, breath therapy, music therapy, balneotherapy, food therapy, laugh therapy etc.

\subsection{Nature Therapy}

Nature therapy is a cure system which treats diseases only with natural cures available around us, like sunlight, weather, water, food diets and healing power that are within us.

\subsection{Spa}

Spa is a place which provides health care facilities with taking advantage of hydrotherapy (mineral hot water, salty or fresh), covering mud, herbal baths, nutrient food etc, where it is assumed that healthy people perform wellness trainings to prevent from disease [10]. Isfahan province with possessing springs like mineral hot water spring of Varton has the potential for investment in this field.

\subsection{Psammotherapy or Sand Therapy}

Hot sands are using for treatment lots of diseases like muscular system-skeletal, scoliosis, arthritis, osteoarthritis and rheumatoid. In addition sand therapy is effective on nervous sicknesses [11]. Because of Isfahan's natural warm weather implying sand therapy and using hot sand baths is obvious.

\subsection{Aromatherapy}

Aromatherapy is the art and science of choosing, mixing and implying volatile oil extacted from plants in order to cure imbalance and heterogeneity in sicks after necessary counseling and assessments [12].

\subsection{Hydrotherapy}

Hydrotherapy is an appropriate non-pharmacological cure which could decrease the pain, increase muscles and bones flexibility and as a result decreasing muscle-skeletal spasms and increasing the power and ability of person [13].

\subsection{Reiki}

Reiki is one of the natural therapy cures that made base on vital energy of the world. This method has been registered for Doctor Mikao Usoi. He had the ability of Reiki energy transfer in addition he could used others as energy transfer canals [14]. 


\subsection{Massage}

Massage is mechanical movement operation on the outer surface of the body which performs with hands, massager devices or water forces and cause to increase blood flow and affects subcutaneous cells and muscles [15].

\subsection{Stone Therapy}

Stones are very effective on healing and self therapy. Each stone has its special benefits and values [16].

\subsection{Color Therapy}

Each person is interested in some colors and has an idea about them. Colors are effective on all aspects of our life. With suitable and right selection of colors, we could improve our life, sprit, mentality and mind [17].

\subsection{Music Therapy}

Music is a phenomenon that causes tranquility and relaxation. With regular use of music, music therapist would change patient's behavior and reach to his therapeutic goals [18].

\subsection{Homeopathy}

Homeopathy's definition is similar treatment. In other hand each factor that cause sickness in a healthy person, can cure others with this disease [19].

\subsection{Acupuncture}

Acupuncture is taken from 2 Latin words:

- Acus means needle, top;

- Pungere means to puncture. Therefore Acupuncture means to stick the needle into special spots for therapeutic purposes [20].

\subsection{Animal Therapy}

In 1980 Friedman had suggested 3 methods that animals improve people's health: first decrease loneliness, sense of isolation and depression, second decrease anxiety and arousal sympathetic nervous system and third improve physical fitness with providing motivation for sport [21].

\subsection{Bee Therapy}

During last ages people took advantage of honey Bee and its products like honey, the venom stings, Pylarnyl, pollen, royal jelly and Propolis [22].

\subsection{Balneotherapy}

Therapeutic use of springs mineral water and salty seas by immersing patient's body there, called Balneotherapy [23]. 


\subsection{Laugh Therapy}

Laugh with set the level of safety, reduce stress, regulate blood pressure and decrease the pain cause to improving quality of life and reducing depression [24].

\subsection{Yuga Therapy}

Yuga means the union of body, mind and spirit. Public belief is that Yuga has resulted in stress reduction and improves breathing, making powerful and flexible body [25].

\subsection{Leech Therapy}

Ayurveda (Indian traditional medicine) has introduced Leech therapy as a systematic process of passing blood from vessels. Leechs are useful for skin diseases, pain management, infection, wound management, not healing wounds, erysipelas, herpes, abscesses and tumors [26].

\subsection{Meditation}

Meditation is a spiritual and remedial action and a consciousness mental process that by regulating concentration on chosen subjects (audio and the image) in specified time period, causes physiological changes [27].

\subsection{Mud Therapy}

Mud is an important component from nature which contains health improver minerals. Mud could absorb body's toxin, therefore it's effective for preventing lots of diseases. Mud therapy causes cooling and relaxation for body because of keeping the moist on skin for long time (Naturopathy Cure portal). In Isfahan with restoration of Gavkhuni swamp the possibility of using therapeutic natural muds will be provided.

\subsection{Medicinal Plants}

Iran is one of the origins of using the traditional medicines and herbal plants. The provinces that have this potential are include: Khorasan, Sistan \& Baluchestan, Isfahan, Kerman, Semnan, Hamadan, Qom and Yazd [28].

\section{Materials and Methods}

In this survey, 50 questionnaires have been distributed among experts in medical science university, municipality and cultural heritage organization that 35 numbers of them collected. After that with Cronbach's alpha validity has been checked. Because the lack of experts low validity reached. With eliminating of 3 questions from questionnaires 0.7 Cronbach's alpha obtained and its validity has been accepted. Finally with taking advantage of SPSS software and square 2 model analyzing and evaluating the answers has been performed.

\subsection{Analysis of the Questionnaire Data}

According to research findings, it's clear that our experts did not have enough expe- 
rience from nature therapy and most of them using chemical medicines (Tables 1-11).

Table 1. Frequency of answers for question number 6.

\begin{tabular}{cccc}
\hline Cumulative frequency percent & Frequency percent & Frequency & \\
\hline 11.4 & 11.4 & 4 & Very high \\
40 & 28.6 & 10 & Very \\
74.3 & 34.3 & 12 & Average \\
88.6 & 14.3 & 5 & Little \\
100 & 11.4 & 4 & Very low \\
& 100 & 35 & Total \\
\hline
\end{tabular}

Table 2. Statistical data of question number 6.

\begin{tabular}{cc}
\hline $8.000 \mathrm{a}$ & 2 -square test \\
4 & Freedom degree \\
0.092 & Significant \\
\hline
\end{tabular}

Table 3. Frequency of answers for question number 7.

\begin{tabular}{ccccc}
\hline Valid frequency percent & Frequency percent & Frequency & & Data \\
\hline 19.4 & 17.1 & 6 & Very high & Valid \\
19.4 & 17.1 & 6 & Very & \\
38.7 & 34.3 & 12 & Average & \\
6.5 & 5.7 & 2 & Little & \\
16.1 & 14.3 & 5 & VERY low & Missing \\
100 & 88.6 & 31 & Total & Total \\
\hline
\end{tabular}

Table 4. Statistical data of question number 7.

\begin{tabular}{cc}
\hline $8.516 \mathrm{a}$ & 2 -square test \\
4 & Freedom degree \\
0.074 & Significant \\
\hline
\end{tabular}

For question number 7 (is it possible to replace nature therapy instead of medical cure?) experts did not make special differences among items and null hypothesis has been accepted: mismatch the replacement of wellness tourism with medical tourism.

This answer showed that from experts' opinion nature therapy could not response to all sicknesses and the importance of surgery centers and chemical medicines could not annoyed.

From question number 2 data (to what extent we can use alternate cures and nature 
Table 5. Frequency of answers for question number 2.

\begin{tabular}{ccccc}
\hline Valid frequency percent & Frequency percent & Frequency & & Data \\
\hline 17.6 & 17.1 & 6 & Very high & Valid \\
41.2 & 40 & 14 & Very & \\
29.4 & 28.6 & 10 & Average & \\
8.8 & 8.6 & 3 & Little & \\
2.9 & 2.9 & 1 & Very low & \\
100 & 97.1 & 34 & Total & \\
& 2.9 & 1 & System & Missing \\
& 100 & 35 & & Total \\
\hline
\end{tabular}

Table 6. Statistical data of question number 2 .

\begin{tabular}{cc}
\hline $16.294 \mathrm{a}$ & 2-square test \\
4 & Freedom degree \\
0.003 & Significant \\
\hline
\end{tabular}

Table 7. Statistical data of question number 3.

\begin{tabular}{cc}
\hline $15.438 \mathrm{a}$ & 2-square test \\
4 & Freedom degree \\
0.00 & Significant \\
\hline
\end{tabular}

Table 8. Statistical data of question number 5 .

\begin{tabular}{cc}
\hline $14.114 \mathrm{a}$ & 2-square test \\
2 & Freedom degree \\
0.001 & Significant \\
\hline
\end{tabular}

Table 9. Statistical data of question number 9.

\begin{tabular}{cc}
$16.543 \mathrm{a}$ & 2 -square test \\
3 & Freedom degree \\
0.001 & Significant \\
\hline
\end{tabular}

Table 10. Statistical data of question number 10.

\begin{tabular}{cc}
$11.000 \mathrm{a}$ & 2-square test \\
3 & Freedom degree \\
0.012 & Significant \\
\hline
\end{tabular}

Table 11. Statistical data of question number 11.

\begin{tabular}{cc}
\hline $23.647 \mathrm{a}$ & 2-square test \\
4 & Freedom degree \\
0.00 & Significant \\
\hline
\end{tabular}


therapy instead of chemical medicine?), answer showed that most of the experts had positive attitude about nature therapy.

In addition question number 3 answers showed that $99 \%$ of experts accepted that existing a place with recreational goal besides health centers is successful.

Answers to question 5 (to what extent are you eager to spend weekends with your family in a place with healthy entertainments?) showed that they would prefer such recreations in their weekends.

According to experts response to question 9 (when you do not have any special disease do you think that nature therapy could prevent from catching lots of sicknesses?) it is clear that $99 \%$ of them agreed that nature therapy could prevent from diseases.

Also question number 10 showed that experts believed mixture of medical with nature therapy not only result in better recovery but also it would speed up sickness preventation.

Finally results showed that expert accepted that: if a person grows up with suitable diet and natural cures, he would not need any emergency and medical surgery cures.

\subsection{Review of the Questions and Research Hypothesis}

1) Is it possible to replace nature therapy instead of medical cure in Isfahan province?

Despite the ancient history of Iran in traditional medicine and Avecinna's teaching in his qanoon book, today this science is obsolete in our country. According to questionnaire results, experts did not believe in totally replacing the natural cures with medical, but they accepted that nature therapy is useful for preventation. In addition they insist on necessity of existing the wellness tourism center in Isfahan province.

2) What is the most important factor for planning the wellness tourism center?

The majority of experts mentioned availability as the most important factor for constructing this center. In addition they believed that this center should be a place far from pollutants and possess favorable climate, suitable affordable costs for using all society groups and a place for improving quality of people's life and promoting communities' health. Therefore second hypothesis has been accepted.

3) What is the most attractive part of nature therapy for citizens of Isfahan?

According to expert's opinion most people prefer massage therapy and third hypothesis (The most attractive part of nature therapy for citizens is hydrotherapy) is rejected. Hydrotherapy was their second priority.

\section{Conclusions}

To reaching this goal, internal and external texts about health tourism have been considered. Results have shown that health tourism has 3 times more benefits than mass tourism and it includes wellness tourism, medical tourism, curative tourism, therapeutic tourism and preventive tourism. Curative and medical tourism for sicknesses and wellness, and therapeutic and preventive tourism for healthy people have been considered. In fact therapeutic and preventive tourisms are wellness tourism's subdivisions. Furthermore wellness tourism is the largest and the most profitable part of health tour- 
ism.

The purpose of constructing the wellness tourism center in Isfahan is to create a place for outdoor recreation for healthy people to prevent from diseases and to make body and soul healthier. The results had shown the eagerness of people and experts for building such a place in Isfahan city.

\section{References}

[1] Harahsheh, S.S. (2002) Curative Tourism in Jordan and Its Potential Development. Thesis for the Fulfillment of MA in European Tourism Management, Bournemouth University, United Kingdom.

[2] Smith, M. and Puczko, L. (2009) Health and Wellness Tourism. Elsevier, USA.

[3] Pollock, A. and Willims, P. (2000) Health Tourism Trends: Closing the Gap between Health Care and Tourism. In: Granter, W. and Lime, D., Eds., Trends in Outdoor Recreation, Leisure and Tourism, CAB Publishing, Oxon, UK, 165-173. http://dx.doi.org/10.1079/9780851994031.0165

[4] Stanford Research Institute (SRI). http://www.sri.com/blog/wellness-tourism-growth-opportunity-worldwide

[5] Kargar, M. (2007) Urban and Tourism Industry Development in Iran. The Arm Forces Organization Publication, Iran, $330 \mathrm{p}$.

[6] Tourani, S., Tabibi, J., Tofighi, S. and Shaarbafchi Zadeh, N. (2010) Medical Tourism in Iran. Research Journal of Biomedical Sciences, 5, 251-257.

[7] Shalbafian, A. (2006) Health Tourism Development Strategies (A Medical Tourism Perspective). MS Thesis, Allameh Tabatabai University. (In Persian)

[8] Anne, D. (2013) Wellness Travel: 10 Trends for 2014 and Beyond. http://Travelmarketreport.com

[9] Patwardhan, B., Mutalik, G. and Tillu, G. (2015) Chapter 6-Life Style and Behavior. In: Integrated Approach for Health, Elsevier Inc., USA. http://dx.doi.org/10.1016/B978-0-12-801282-6.00006-1

[10] Lukashuk, L. (2014) Sand Therapy or Psammotherapy. http://lecheniebolezni.com/encreativework/lechenye-peskom-yly-psammoterapyya

[11] Naturopathy Cure. http://naturopathycure.com/Mud-Therapy-Benefits.php

[12] Lehto, X., Brown, S., Chen, Y. and Morrison, A. (2006) Yoga Tourism as a Niche within the Wellness Tourism Market. Tourism Recreation Research, 31, 25-35. http://dx.doi.org/10.1080/02508281.2006.11081244

[13] Friedmann, E., Son, A. and Saleem, M. (2015) The Animal-Human Bond: Health and Wellness. In: Chapter 7, Handbook on Animal-Assisted Therapy, Academic Press, USA, 73-88.

[14] Ellis, S. (2013) The Global Wellness Tourism Economy. ITB Experts Forum Wellness, Global Spa and Wellness Summit.

[15] Hashemian, K. (2004) Effects of Music Applying in Healing the Body and Spirit. Community of Applying Music in Physical and Mental Health, Iran.

[16] Moshtaghe Eshgh, Z., Naghavi, B., Reshvand, F., Majd, H.A. and Banaderakhshan, H. (2010) Considering the Effects of Laugh Therapy on Tiredness and depression among Sicks Affected by M.S. Visiting in M.S. Institute of Iran. Scientific Journal of Nursing and Midwifery, No. 70, 7-11.

[17] Moradi Asl, E., Vatandust, H., Sheshmad, K., Salari, M. and Rafinezhad, J. (2013) A Review 
on Bee Therapy in Iran and the World. No. 1, 178-188,

[18] Feizi, V. and Mortazavi, H. (2013) Therapeutic Using from Mineral Water Springs and Seas for General and Dermal Sicknesses (Balneotherapy). Payesh Quarterly, No. 3, 225-230.

[19] Shirazian, B. (2007) Aromatherapy and Massage. Ferdos Publication, Iran.

[20] Shupe, F. and Hajhadi, B. (2001) Sport Massage and Massage Therapy Science. Elsevier, USA.

[21] Sabzalian, F. (2004) Healing with Extrasensory. Faragoft Publication, Iran.

[22] Rezvani, M. (2011) Acupuncture Definition from West View. Scientific Quarterly of Anesthesia and Pain, No. 4.

[23] Shafia, S., Hemmati, Z., Meskini, L. and Khalilian, A. (2008) Survey of Awareness and Attitude of Physicians about Homeopathy Cure in Sari Province. Medical Science Journal of Mazandaran, No. 66, 102-103.

[24] Dehghani, S., Amini, K., Shakibazade, E., Faghihzade, S. and Hashemzade, M. (2014) Meditation Impact of 2 Heart on Nervous Amount of Hemodializ Sicks. Journal of Preventive Care in Nursery and Midwifery, No. 2, 56-65.

[25] Hosseini, M., Atashpur, H. and Aghai, A. (2008) Psychology on Education Spaces Architecture of Healthy City. First Congress of Healthy City, Iran.

[26] Bekhradi, R. and Khayatkashani, M. (2006) Herbal Essence Therapy Application. Morsal Publication, Iran.

[27] Ghafari, S., Ahmadi, F. and Nabavi, S.M. (2008) Survey about Impact of Water Therapy on M.S. Sicks Tiredness. Mazandaran University of Medical Science Journal, No. 66, 71-81,

[28] Nuri Hekmat, S., Jabbari, A., Denoye, R. and Mardani, R. (2014) Hospitals Readiness for Entering to Medical Tourism Industry: Isfahan Province, Health Information Management. No. 4, 20-32.

Submit or recommend next manuscript to SCIRP and we will provide best service for you:

Accepting pre-submission inquiries through Email, Facebook, LinkedIn, Twitter, etc. A wide selection of journals (inclusive of 9 subjects, more than 200 journals)

Providing 24-hour high-quality service

User-friendly online submission system

Fair and swift peer-review system

Efficient typesetting and proofreading procedure

Display of the result of downloads and visits, as well as the number of cited articles

Maximum dissemination of your research work

Submit your manuscript at: http://papersubmission.scirp.org/

Or contact oje@scirp.org 